\title{
Comparative antiproliferation of human prostate cancer cells by ethanolic extracts of two groups of Brazilian propolis
}

\author{
Antiproliferação comparativa de células prostáticas humanas \\ por extratos etanólicos de dois grupos de própolis brasileira
}

\author{
Cleber Silveira MORAES ${ }^{1}$, Andreas DAUGSCH${ }^{1}$, Hongzhen $\mathrm{LI}^{2}$, Johng Suk RHIM², Yong Kun PARK ${ }^{1 *}$
}

\begin{abstract}
Two groups of propolis, group 12, which was collected in the southeastern Brazil and group 13, which was collected in the northeastern Brazil, were examined for antiproliferation of primary malignant tumor (RC-58T/h/SA\#4)-derived human prostate cancer cells and human prostate epithelial cells. The strongest inhibition of RC-58T/h/SA\#4 cells was observed in propolis group 13 extracts, whereas moderate growth inhibition was observed in human prostate epithelial cells in comparison with group 12. It can be said that the Brazilian propolis of group 13 contains important chemical ingredients.
\end{abstract}

Keywords: prostate cancer; antiproliferation; propolis.

\section{Resumo}

Própolis de dois grupos, do grupo 12, coletada no sudeste do Brasil, e do grupo 13, coletada no nordeste do Brasil, foram examinadas quanto à antiproliferação de tumor maligno primário (RC-58T/h/SA\#4), derivado de células de câncer prostático humano e células epiteliais prostáticas humanas. A inibição mais forte de células RC-58T/h/SA\#4 foi observada no extrato de própolis do grupo 13, enquanto que foi observada inibição de crescimento moderada em células epiteliais prostáticas humanas no grupo 12. Conclui-se que a própolis brasileira do grupo 13 contém importantes ingredientes químicos.

Palavras-chave: câncer de próstata; antiproliferação; própolis.

\section{Introduction}

Propolis is a resinous substance collected by honey bees (Apis mellifera) from various tree buds which they use to coat hive parts and to seal cracks and crevices in the hive to protect the entrance against intruders (GREENAWAY; SCAYSBROOK; WHATLEY, 1990). Propolis has been used as folk medicine since ca. $300 \mathrm{BC}$, and it has also been reported that propolis has a wide range of biological activities including antioxidant, antimicrobial, anti-inflammatory, anti-tumoral, anti-HIV, and anti-dioxins (GHISALBERTI, 1979; BURDOCK, 1998; PARK et al., 2005). Recently, propolis has also been extensively used in foods and beverages as an ingredient of functional foods to improve health and prevent diseases (BURDOCK, 1998; PARK et al., 2004). These applications of propolis have led to increased interest in its chemical compositions because so far mainly polyphenol compounds have been identified in propolis collected by Apis mellifera, and the major polyphenols are flavonoid aglycones and their derivates (KONIG, 1985).

The chemical composition of the major flavonoids in propolis has been found to be quantitatively or qualitatively variable, depending on the environmental plant ecology (MARCUCCI,
1995; PARK; ALENCAR; AGUIAR, 2002; PARK et al., 2004). Previously, we collected 500 samples of propolis obtained by the Africanized Apis mellifera in Brazil which were analyzed. We found that the Brazilian propolis is classified into 12 groups based on their physicochemical characteristics, and some of the ethanolic extracts of propolis inhibited the growth of rapidly growing solid tumor cell lines (PARK; ALENCAR; AGUIAR, 2002). As result, it was found that groups 1, 2, 6, and 7 are highly antagonistic to the growth of nasopharyngeal carcinoma (KB), and groups 6 and 7 are highly inhibitive against the growth of ileocecal adenocarcinoma (HCT-8), renal carcinoma CAKE-1, and breast carcinoma (MCT-7) tumor cell lines (MARCUCCI, 1995; PARK et al., 2000).

Among human cancer, prostate cancer is the most common male cancer and the second leading cause of male cancer death in the USA (JEMAL et al., 2005). Despite its pervasive impact, the etiology of prostate cancer and the factors that promote its progression are not well understood. To date, there is no secure way to tell whether prostate cancer, once found, should

Department of Food Science, College of Food Engineering, State University of Campinas - UNICAMP, CEP 13081-970, P.O. Box 6177, Campinas - SP, Brazil,

E-mail: ykpark@fea.unicamp.br

${ }^{2}$ Center for Prostate Disease Research, Uniformed Services University of the Health Sciences - USUHS, Bethesda - MD, USA

${ }^{*}$ A quem a correspondência deve ser enviada 
receive treatment. Although prostatectomy, radiation therapy, and hormone therapy have been used for curing prostate cancer patients, recurrence and metastasis of prostate cancer are major problems in prostate cancer therapy. Current available treatment often has troubling side-effects such as urinary incontinence and erectile dysfunction. There is no effective treatment modality once the cancer has evolved into the hormone refractory stage. Preventive strategies are currently emerging. There has been an increase in the usage of nutritional supplements such as soybeans, garlic, green tea, Vitamin $\mathrm{D}_{3}$, etc., to augment the prescribed anticancer therapies.

Consequently, among the 12 groups of propolis, group 12, which can be obtained in southeastern and central western Brazil, has been extensively used in foods and beverages to improve health and prevent diseases. Furthermore, recently, red propolis from beehives, located along the sea and river shores in northeastern Brazil, has been found. The botanical origin of the red propolis is Dalbergia ecastophyllum, and this propolis showed higher antimicrobial activity and is classified as propolis group 13 (DAUGSCH et al., 2008). We evaluated the effects of Brazilian propolis groups 12 and 13 on the proliferation of primary tumor-derived human prostate cancer cells.

\section{Materials and methods}

\subsection{Preparation of experimental samples}

Two ethanolic extracts of propolis groups 12 and 13 were prepared as follows. Each group of propolis samples (50 g) was extracted with $600 \mathrm{~mL}$ of $80 \%(\mathrm{v} / \mathrm{v})$ ethanol at $60{ }^{\circ} \mathrm{C}$ for 30 minutes After extraction, the mixture was centrifuged, the supernatant fluids were evaporated to complete dryness at $40^{\circ} \mathrm{C}$,

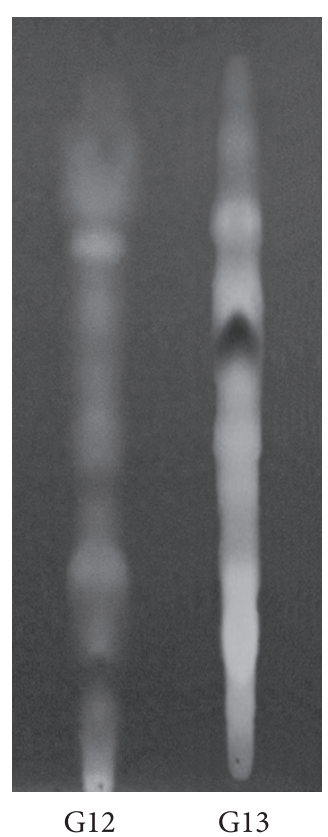

Figure 1. RPHPTLC of ethanolic extracts of Brazilian propolis groups 12 and 13. and the resulting powder were designated as ethanolic extract of propolis. The two samples were analyzed by Reversed-Phase High-Performance Thin-Layer Chromatography (RPHPTLC) and Reversed-Phase High-Performance Liquid Chromatography (RPHPLC). The results are shown in Figures 1 and 2 and in Table 1. Genistein, a soybeans isoflavone, was used as positive control, and it was purchased from Sigma (St. Louis, MO).

\subsection{Reversed-Phase High-Performance Thin-Layer Chromatography (RPHPTLC)}

Precoated plates of silica gel RP-18F254S for RPHPTLC were purchased from Merck Co. A $3 \mu \mathrm{L}$ portion of the ethanolic extract of propolis was applied to the lower edge of the plate, and ascending chromatography was run using a mobile phase of ethanol/water $(55: 45, \mathrm{v} / \mathrm{v})$. The detection of flavonoids was carried out using UV-visualization at $366 \mathrm{~nm}$ (ISLA et al., 2005).

\subsection{Reversed-Phase High-Performance Liquid Chromatography (RPHPLC)}

The analysis of flavonoids and other phenolic compounds from ethanolic extracts of propolis was performed by RPHPLC with a chromatograph equipped with an YMC Pack ODS-A
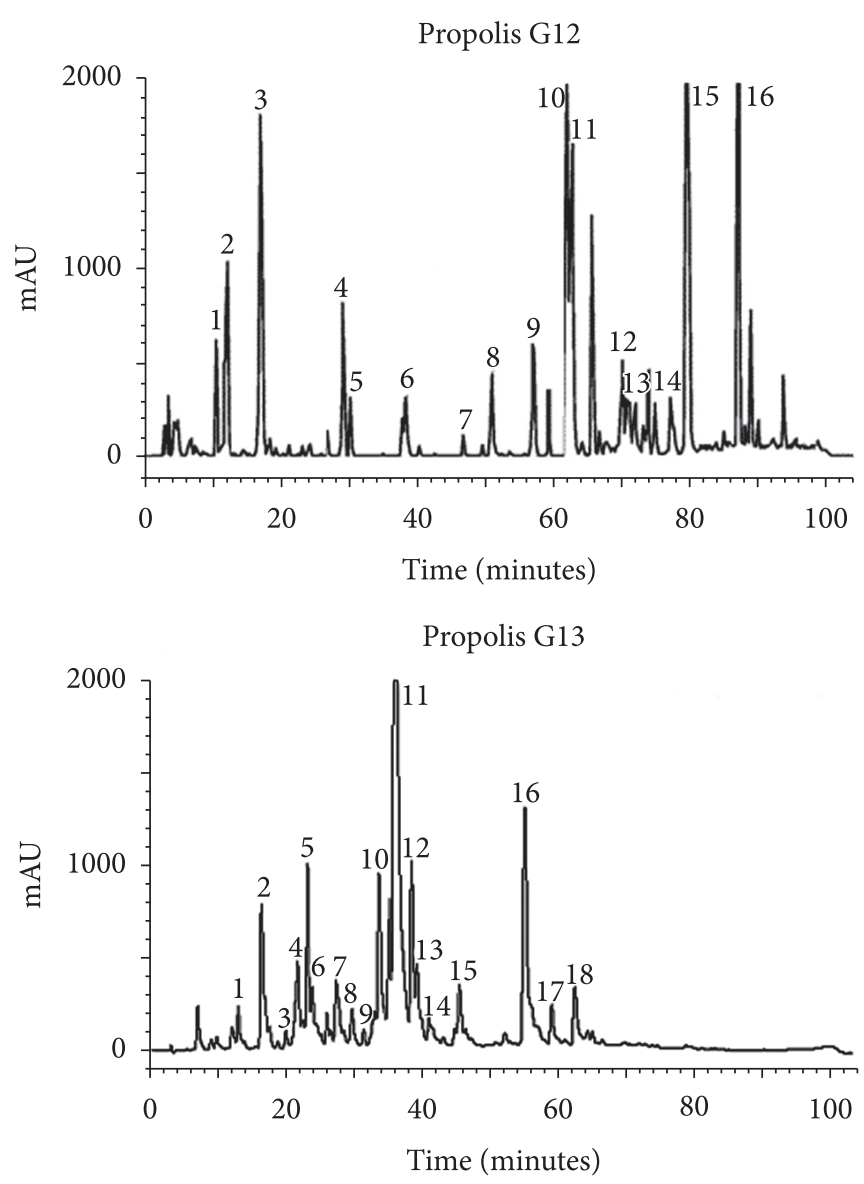

Figure 2. RPHPLC chromatograms of ethanolic extracts of propolis groups 12 and 13. 
column (RP-18, column size $4.6 \times 250 \mathrm{~mm}$; particle size $5 \mu \mathrm{m}$ ) and photodiode array detector (SPD-M10A, Shimadzu Co.). The column was eluted by using a linear gradient of water (solvent $\mathrm{A}$ ) and methanol (solvent B), starting with 30\% B (0-15 minutes) and increasing to $90 \% \mathrm{~B}$ (15 - 75 minutes), held at $90 \%$ B (75-95 minutes), and decreasing to $30 \%$ B (95-105 minutes) with a solvent flow rate of $1 \mathrm{~mL} /$ minute and detection with a diode array detector. Chromatograms were recorded at $268 \mathrm{~nm}$. The authentic standards of flavonoids and other chemical ingredients were purchased from Extrasynthese Co., France (PARK et al., 2005).

\subsection{Cell culture}

Telomerase-immortalized primary human prostate cancerderived cell line (RC-58T/h/SA\#4) and primary human prostate epithelial cells (PrEC) (Cambrex Bioproducts, Walkersville, $\mathrm{MD})$ were grown and maintained in the keratinocyte serum free medium (K-SFM) supplemented with bovine pituitary extract and recombinant epidermal growth factor (KGM) (Life Technologies, Inc. Gaithersburg, MD) (LI et al., 2007).

\subsection{Cell proliferation assays}

The cell growth assays were carried out using CellTiter 96 Aqueous One solution cell proliferation assay kit (Promega, WI). Briefly, 5000 cells/well were plated in 96-well plates, and desired concentrations of propolis were added on the following day. After treatment for 48 hours, detection reagents (MTS) were added, and cells were incubated for 1 hour. The absorbance was measured at $492 \mathrm{~nm}$ in 96-well plate reader (LI et al., 2007).

\section{Results and discussion}

\subsection{Propolis groups 12 and 13}

As described in previous publication (PARK; ALENCAR; AGUIAR, 2002), group 12 was identified in the southeastern Brazil, and the botanical origin of this propolis was the Baccharis dracunculifolia bud resinous exudates and recently, ithas been observed that honeybees collect the red resinous exudates on the surface of Dalbergia ecastophyllum to produce propolis in the northeastern Brazil. This propolis was classified as group 13. The samples of both propolis were analyzed by RPHPTLC. As shown in Figure 1, chemical ingredients of both propolis were entirely different, therefore, some ingredients were identified using RPHPLC, and the results are shown in Figure 2 and Table 1 , respectively. 16 chemical ingredients were identified in propolis group 12, and the major compound in the extract was artepillin C (3,5-diprenyl-4hydroxycinamic acid), which was reported to inhibit lipid peroxidation and the development of pulmonary cancers (KIMOTO et al., 2001). In addition, artepillin $\mathrm{C}$ has a tumor suppressing effect not only by directly inhibiting tumor cell growth, but also by inhibiting angiogenesis (AHN et al., 2007). With regard to propolis group 13, 18 chemical ingredients were identified, and the major compound in the extract was formononetin, which is an isoflavonoid, including daidzein and biochanin A. These isoflavonoids have a very restrict distribution in the plant and occur almost exclusively in the Leguminose family (INGHAM, 1983). Dietary consumption of foods and food additive containing isoflavones have been associated with a variety of health benefits (ADLERCREUTZ et al., 1995).

Table 1. Flavonoids and other chemical constituents of propolis groups 12 and 13, determined by RPHPLC (mg.g ${ }^{-1}$ ).

\begin{tabular}{|c|c|c|c|c|c|}
\hline \multicolumn{3}{|c|}{ Propolis G12 } & \multicolumn{3}{|c|}{ Propolis G13 } \\
\hline Peak no. & Compound & $\begin{array}{l}\text { Quantity in mg.g }{ }^{-1} \text { of } \\
\text { propolis }\end{array}$ & Peak no. & Compound & $\begin{array}{c}\text { Quantity in mg.g }{ }^{-1} \text { of } \\
\text { propolis }\end{array}$ \\
\hline 1 & Coumaric acid & 10.7 & 1 & Rutin & 1.3 \\
\hline 2 & Ferulic acid & 2.4 & 2 & Liquiritigenin & 7.1 \\
\hline 3 & $\Lambda 245 \mathrm{~nm}^{\mathrm{a}}$ & + & 3 & Daidzein & 4.3 \\
\hline 4 & Cinnamic acid & 2.6 & 4 & Pinobanksin & 6.0 \\
\hline 5 & Pinobanksin & 1.7 & 5 & $\Lambda 251,292 \mathrm{~nm}^{\mathrm{a}}$ & + \\
\hline 6 & Kaempferol & 1.3 & 6 & Quercetin & 1.9 \\
\hline 7 & Isosakuranetin & 4.9 & 7 & Luteolin & 2.1 \\
\hline 8 & Chrysin & 1.9 & 8 & $\Lambda 241,272,281 \mathrm{~nm}^{\mathrm{a}}$ & + \\
\hline 9 & Acacetin & 6.7 & 9 & Dalbergin & 0.9 \\
\hline 10 & Kaempferide & 12.6 & 10 & Isoliquiritigenin & 12.1 \\
\hline 11 & $\Lambda 244 \mathrm{~nm}^{\mathrm{a}}$ & + & 11 & Formononetin & 19.5 \\
\hline 12 & $\Lambda 230 \mathrm{~nm}^{\mathrm{a}}$ & + & 12 & $\Lambda 235,263 \mathrm{~nm}^{\mathrm{a}}$ & + \\
\hline 13 & $\Lambda 245 \mathrm{~nm}^{\mathrm{a}}$ & + & 13 & Pinocembrin & 7.1 \\
\hline 14 & $\Lambda 228,246 \mathrm{~nm}^{\mathrm{a}}$ & + & 14 & Pinobanksin 3-acetato & 2.6 \\
\hline 15 & Artepillin C & 38.6 & 15 & Biochanin A & 1.5 \\
\hline \multirow[t]{3}{*}{16} & $\Lambda 223,276 \mathrm{~nm}^{\mathrm{a}}$ & + & 16 & $\Lambda 238,260,269 \mathrm{~nm}^{\mathrm{a}}$ & + \\
\hline & & & 17 & $\Lambda 233,249,329 \mathrm{~nm}^{\mathrm{a}}$ & + \\
\hline & & & 18 & $\Lambda 233,256 \mathrm{~nm}^{\mathrm{a}}$ & + \\
\hline
\end{tabular}

${ }^{a}$ Unidentified constituents represent only UV spectral absorption maxim; and + Present, but not quantified. 


\subsection{Inhibition of cell growth by two propolis samples}

When the cells were growing in the serum free medium (KGM), propolis groups 12 and 13 showed similar inhibition against the growth of RC-58T/h/SA\#4 (LI et al., 2007) and PrEC cells, but group 13 demonstrated higher growth inhibition than group 12, as shown in Figure 3, and two propolis samples showed higher inhibitory efficiency in malignant cells (RC$58 \mathrm{~T} / \mathrm{h} / \mathrm{SA \# 4)}$ ) than normal prostate epithelial (PrEC). The 50\% growth inhibition (GI50) of propolis was $5 \mu \mathrm{g} \cdot \mathrm{mL}^{-1}$ for propolis group 12 and $2.75 \mu \mathrm{g} \cdot \mathrm{mL}^{-1}$ for group 13 in RC-58T/h/SA\#4 cell, but 8.75 and $3.25 \mu \mathrm{g} \cdot \mathrm{mL}^{-1}$ in PrEC cell, as shown in Table 2.

Table 2. The fifty percent growth inhibition (GI50) of normal human prostate epithelial cells (PrEC) and primary tumor-derived human prostate cancer cells (RC-58T/h/SA\#4) by propolis groups 12 and 13 .

\begin{tabular}{lcc}
\hline \multicolumn{1}{c}{ Cells/propolis } & PrEC $^{*}$ & RC-58T/h/SA\#4 ${ }^{*}$ \\
\hline Propolis G12 & 8.75 & 5.00 \\
Propolis G13 & 3.25 & 2.75 \\
\hline${ }^{*}$ Cell grew in KGM medium & &
\end{tabular}

Effect of propolis samples on PrEC cells' growth

(a)

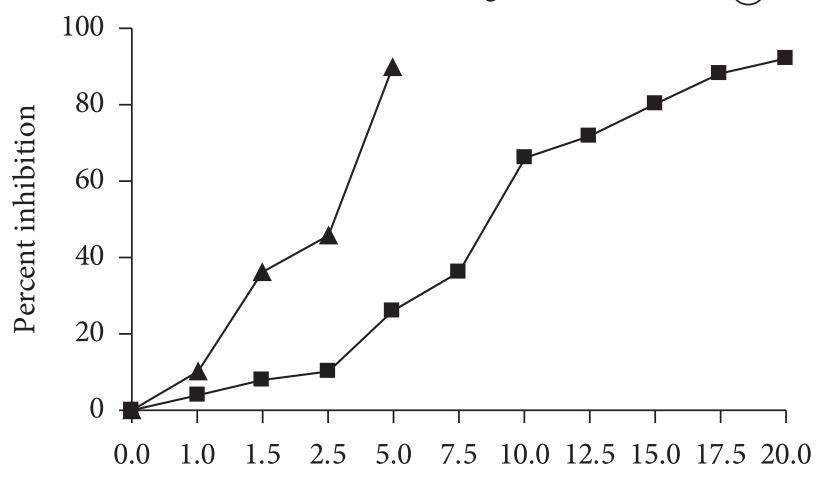

Concentration $\left(\mu \mathrm{g} \cdot \mathrm{mL}^{-1}\right)$

Effect of propolis samples on $\mathrm{RC}-58 \mathrm{~T} / \mathrm{h} / \mathrm{SA} 44$ cells' growth

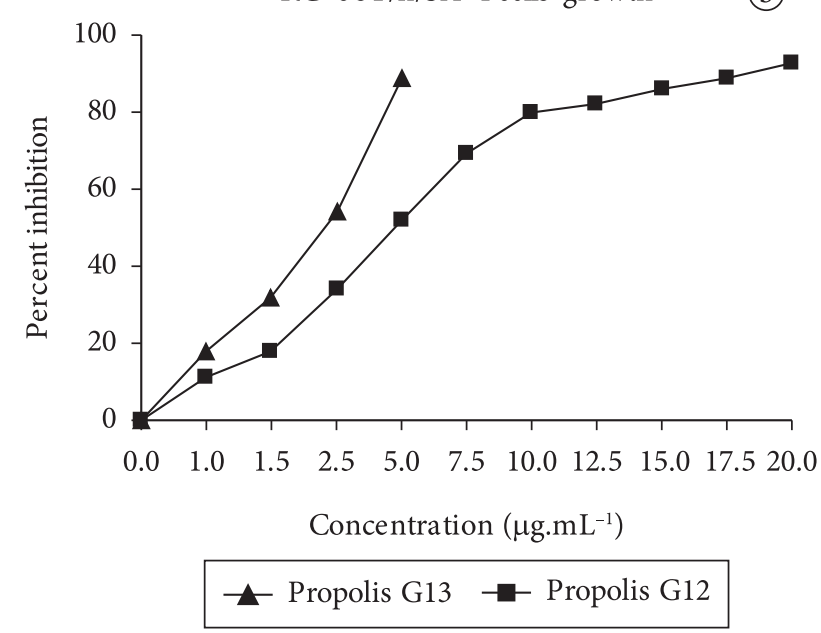

Figure 3. Effect of propolis samples on cells' growth.

\section{Conclusions}

Previously, we tested the cell viability of RC-58T/h/ SA\#4 and PrEC cells with propolis group 12 . The $50 \%$ growth inhibition (GI50) of propolis was $5 \mu \mathrm{g} \cdot \mathrm{mL}^{-1}$, and the sample had higher inhibitory efficiency in primary prostate cancer cells compared to normal human prostate epithelial cells. The results suggested that propolis group 12 could be useful alone or in combination with anticancer agents in prostate cancer chemotherapy as well as cancer chemoprevention. Therefore, we compared with propolis group 12 and group 13 in this experiment, and it was found that propolis group 13 showed higher inhibitory efficiency than group 12.

\section{Acknowledgements}

The authors are grateful for the financial support provided by the CAPES (Brazilian research supporting foundation) and to Mr. Edivaldo Pacheco (Apiário Edimel, João Pessoa - Paraíba, Brazil) and Mr. José Alexandre Abreu (Pharmanectar Ltd, Belo Horizonte - Minas Gerais, Brazil) for the collection of Dalbergia ecastophyllum.

\section{References}

ADLERCREUTZ, C. H. et al. Soybean phytoestrogen intake and cancer risk. Journal of Nutrition, v. 125, p. 757S-770S, 1995.

AHN, M. et al. Suppression of tumor-induced angiogenesis by brazilian propolis: major component artepillin $\mathrm{C}$ inhibits in vitro tube formation and endothelial cell proliferation. Cancer letters, v. 252, p. 235-243, 2007.

BURDOCK, G. A. Review of the biological properties and toxicity of bee propolis. Food Chemistry Toxicology, v. 36, p. 347-363, 1998.

DAUGSCH, A. et al. Brazilian red propolis-chemical composition and botanical origin. Evidence-Based Complementary and Alternative Medicine, v. 5, p. 435-441, 2008.

GHISALBERTI, E. L. Propolis: a review. Bee World, v. 60, p. 59-84, 1979.

GREENAWAY, W.; SCAYSBROOK, T.; WHATLEY, F. R. The composition and plant origins of propolis. Bee World, v. 71, p. 107-118, 1990.

INGHAM, J. L. Naturally occurring isoflavonoids. Progress in the chemistry of organic natural products, v. 43, p. 1-26, 1983.

ISLA, M. I. et al. Some chemical composition and biological activity of northern Argentine propolis. Journal of Agriculture and Food Chemistry, v. 53, n. 4, p. 1166-1172, 2005.

JEMAL, A. et al. Cancer statistics. CA: A Cancer Journal of Clinicians, v. 55, p. 10-30, 2005.

KIMOTO, T. et al. Pulmonary carcinogenesis induced by ferric nitrilotriacetate in mice and protection from it by brazilian propolis and artepillin C. Springer Verlag, v. 438, p. 259-270, 2001.

KONIG, B. Plant sources of propolis. Bee World, v. 66, p. 136-139, 1985.

LI, H. et al. Antiproliferation of human prostate cancer cells by ethanolic extracts of brazilian propolis and its botanical origin. International Journal of Oncology, v. 31, p. 601-606, 2007.

MARCUCCI, M. C. Propolis: chemical composition, biological properties and therapeutical activity. Apidologie, v. 26, p. 83-99, 1995. 
PARK, Y. K. et al. Chemical constituents in Baccharis dracunculifolia as the main botanical origin of southeastern brazilian propolis. Journal of Agriculture and Food Chemistry, v. 52, n. 5, p. 1100-1103, 2004.

PARK, Y. K. et al. Suppressive effects of ethanolic extracts from propolis and its main botanical origin on dioxin toxicity. Journal of Agriculture and Food Chemistry, v. 53, n. 26, p. 10306-10309, 2005.
PARK, Y. K.; ALENCAR, S. M.; AGUIAR, C. L. Botanical origin and chemical composition of brazilian propolis. Journal of Agriculture and Food Chemistry, v. 50, n. 9, p. 2502-2506, 2002.

PARK,Y. K. et al. Atividade citotoxica e extracts etanolicos de propolis coletadas em diferentes regioes do Brasil. Mensagem Doce, v. 56, p. $2-5,2000$. 